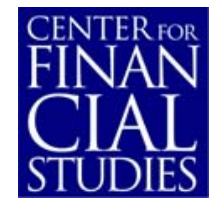

No. $2010 / 02$

Are particular industries more likely to succeed? A comparative analysis of VC investment in the U.S. and Europe

Roman Kraeussl and Stefan Krause 


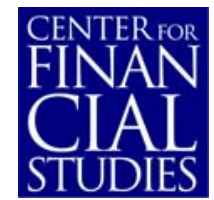

\section{Center for Financial Studies}

The Center for Financial Studies is a nonprofit research organization, supported by an association of more than 120 banks, insurance companies, industrial corporations and public institutions. Established in 1968 and closely affiliated with the University of Frankfurt, it provides a strong link between the financial community and academia.

The CFS Working Paper Series presents the result of scientific research on selected topics in the field of money, banking and finance. The authors were either participants in the Center's Research Fellow Program or members of one of the Center's Research Projects.

If you would like to know more about the Center for Financial Studies, please let us know of your interest.
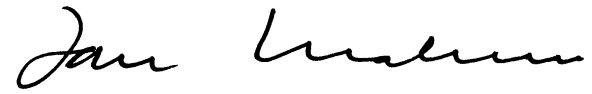

Prof. Dr. Jan Pieter Krahnen 


\title{
Are particular industries more likely to succeed? A comparative analysis of VC investment in the U.S. and Europe
}

\author{
Roman Kraeussl $^{1}$ and Stefan Krause ${ }^{2}$
}

\author{
November 2009
}

\begin{abstract}
:
The objective of this study is to determine whether specific industries across countries or within countries are more likely to reach a stage of profitability and make a successful exit. In particular, we assess whether firms in certain industries are more prone to exit via IPO, be acquired, or exit through a leveraged buy-out. We are also interested in analyzing whether substantial differences across industries and countries arise when looking separately at the success' rate of firms which have received venture funding at the early seed and start-up stages, vis-à-vis firms that received funding at later stages. Our results suggest that, inasmuch as some of the differences in performance can be explained by country-specific factors, there are also important idiosyncratic differences across industries: In particular, firms in the biotech and the medical / health / life science sectors tend to be significantly more likely to have a successful exit via IPO, while firms in the computer industry and communications and media are more prone to exit via merger or acquisition. Key differences across industries also emerge when considering infant versus mature firms, and their preferred exit.
\end{abstract}

JEL Classification: G24, G3

Keywords: Venture Capital, Success Rates, Country Comparison, Industry Comparison, Biotech Firms.

1 VU University Amsterdam and CFS, Corresponding author: Associate Professor of Finance, VU University Amsterdam, FEWEB, de Boelelaan 1105, 1081 HV Amsterdam, The Netherlands, P: +31 20598 6102, F: +31 20598 6020, E: rkraeussl@feweb.vu.nl. 


\section{Introduction}

The objective of this study is to determine whether specific industries across countries or within countries are more likely to reach a stage of profitability and make a successful exit. In particular, we assess whether venture capital-backed firms in certain industries are more prone to exit via an initial public offering (IPO), be acquired, or exit through a leveraged buy-out. We are also interested in analyzing whether substantial differences across industries and countries arise when looking separately at the success' rate of firms which have received venture funding at the early seed and start-up stages, vis-à-vis firms that received funding at latter stages.

To this end, we examine venture capital (VC) investments and exits in the U.S. and the EU-15 countries, throughout the period 1985-2008, while further classifying firms into distinct industries. The dimensionality of our data set allows us to uncover significant relationships and common factors that lead to the success of a venture capital company completing the exit phase.

The comparison between the performance of VC funds in the U.S. and European countries has been the subject of much research over the past decade (see Black and Gilson (1998), Bottazi and Da Rin (2002), and Hege, Palomino and Schwienbacher (2009), among others). Differences in stock market development, contract and tax legislation, and labor market regulations, to name a few, have been oft-cited in connection to the consistent underperformance of European VC funds relative to their American counterparts. Even as recently as the pre-crisis period of 2005-2007, there have been no signs of a decrease in the profitability gap between European and U.S. venture capital investment (Raade and Dantas Machado (2008)). While acknowledging and controlling for country-specific differences, our paper attempts to further explore if there exist common elements that may explain how firms in similar industries could achieve a similar likelihood as to the preferred exit.

Another relevant issue that this paper addresses is that of the asymmetry in VC success when separately analyzing investment in seed and start-up versus more mature firms. As documented by Jeng and Wells (2000), early and later stage venture capital investments are affected quite differently by the determinants of venture capital. In particular, we intend to find out if the sub-par returns generated by European early stage 
venture investment, as documented by Raade and Dantas Machado (2008), are more prevalent in specific industries.

Our results suggest that, inasmuch as some of the differences in performance can be explained by country-specific factors (in particular, when considering start-up/seed and early stage firms), there are also important idiosyncratic differences across industries. For instance, firms in the biotech and the medical / health / life science sectors tend to be significantly more likely to have a successful exit via IPO, while firms in the computer industry and communications and media are more prone to exit via merger or acquisition. Important differences across industries also emerge when considering infant versus mature firms, and their preferred exit.

The remainder of this paper is organized as follows: on Section II we provide an overview of our data, followed by a description of how we construct the different variables associated with success rate on Section III. Section IV takes a first look at the empirical results through some summary statistics, while Section V presents the results of our regression analysis. Section VI concludes.

\section{Sample}

Our sample covers the period 1985-2008 and includes data from the U.S. and all EU-15 countries (Austria, Belgium, Denmark, Finland, France, Germany, Greece, Ireland, Italy, Luxembourg, the Netherlands, Portugal, Spain, Sweden, and the United Kingdom). The source of information on venture capital investment, company count, rounds of investment, and outcome/exit is VentureXpert. Data on country specific variables (Gross Domestic Product, Population, and Research and Development figures) stems from Euromonitor and the SourceOECD database. Finally, patent data is obtained from the European Patent Office (EPO, for all patent applications made in the EU-15 countries), and the U.S. Patent Trade Office (USPTO, for all applications made in the U.S. market).

In total, we are able to track the evolution of 51,994 firms that received VC funding, and determine the resulting exit - if any - that each of these firms was able to achieve. Table A1 in the appendix summarizes the composition of this data set: by country, stage of development of the firm when it received its first round of VC funds (start-up and seed, early stage, or mature) and by industry; this latter classification is 
explained in more detail below. As expected, the U.S. is the predominant country of origin of the firms in question (34,088; nearly $2 / 3$ of the entire sample); while we were only able to collect information on 65 and 66 firms for Greece and Luxembourg, respectively.

Given that this paper seeks to determine whether industry specific factors play a significant role in determining the likelihood for a successful venture exit, it would be of great benefit to obtain as many independent industry-specific variables that match to the industry categories identified by VentureXpert. Following Gompers, Kovner, Lerner and Scharfstein (2008), we aim at classifying firms into categories that exhibit similarities in technology and management expertise. This task poses a bit of a challenge, given that the industry trend data is only available based on standardized codes, of which there are many different forms unique to the U.S., the EU overall, and to each of the countries within the EU.

In order to match the data available in International Standard of Industrial Classification (ISIC) codes with the success rates using VentureXpert industry categories, we initially mapped out a categorization table of the VentureXpert industry classification system from its most broad level 'Major Group' down to the most-detailed level titled 'Sub category 3'. Then, by evaluating each line of the ISIC category list, we assign them to their appropriate VentureXpert Sub Category 3 listing. Table A2 in the Appendix presents an overview how this mapping works. The outcome is the classification into 6 main industry groups: computer software and hardware; semiconductors and other electronics; biotechnology; medical, health and life sciences; communications and media; and non-high technology. This allows us to maintain the main recipients of venture capital disbursements (Gompers and Lerner, 2001) separated, while allowing for a reasonable degree of aggregation in the data that will assist us in the empirical analysis.

\section{Measuring Success}

Some previous studies that have looked at how to compute returns to VC investment include Cumming and MacIntosh (2003), who examine a sample of 248 hand-collected VC exits in Canada and the U.S., and Cochrane (2005), who analyzes exits using VentureOne data. In order to measure success of an investment, ideally we would require 
data on the actual returns on venture capital firm's investments. However, this is not possible because neither Venture Economics, nor VentureXpert collect valuation information for all of the companies that have been part of a VC investment fund.

Following Gompers et al. (2008), our proposed measure of 'success' takes into consideration the type of exit of a particular company. We define Success by IPO (S1), as the number of firms that received venture capital investment, and successfully exited via IPO. Success by Acquisition or Merger (S2) is defined analogously, this time considering successful VC-sponsored firms that were either acquired or merged with other firms. Finally, we introduce a measure of Overall Success (OS), which adds $S 1$ and $S 2$ success and includes in addition the cases in which the companies' exits took place through a leveraged buy-out (LBO).

We perform one further classification, which consists in separating the performance of seed/start-up and early stage firms that received VC funds, from the performance of more mature firms. For all company data we recorded whether the firm was an early stage or seed/start-up at the time it received its first VC investment. Success by Infant Firms (IS) is computed as the number of start-up and seed, and early-stage firms funded by VC investment, which successfully exited by going public, through merger or acquisition, or by means of a leveraged buy-out. Similarly, Success by Mature Firms $(M S)$ is computed as the number of established firms receiving VC funds, and successfully exited by any of the above-cited channels.

The success variables are constructed by analyzing all VC investments, with investment domicile determined by company nation. These are then ordered by country, by year and by industry to obtain a success rate, which is defined as the number of VCbacked companies in a given year for a given country that had a successful exit, divided by the total number of $\mathrm{VC}$ invested companies for that given year and country. The year specified in this case is determined by the year in which the first round investment was received. For example, this means that for all companies that received their first round of VC financing in the year 2000, their future success would be attributed to that year of original investment, in this case 2000. 


\section{Descriptive Analysis}

As a first step it is useful to analyze where the difference in success arises from, i.e., to look at a simple comparison between the performance of the U.S. and the EU-15 countries over the period 1985-2008. Table I presents the comparison between the U.S. and EU-15 VC investments and success rates.

\section{Table I}

\section{Comparison between the U.S. and EU-15: Venture Capital and Success by IPO and Acquisition or Merger}

Notes: Success by IPO is computed as the number of firms who successfully exited by initial public offering divided by the total number of firms receiving venture capital funding. Success by Acquisition or Merger is computed as the number of firms who successfully exited by merging with or being acquired by other firms, divided by the total number of firms receiving venture capital funding. Overall Success, adds Success by IPO, Success by Acquisition or Merger, and includes in addition the cases in which the companies' exits took place through a leveraged buy-out (LBO). For all three measures, the rates were computed considering all transactions between 1985 and 2008, by industry and country, and were multiplied by a factor of 100 .

\begin{tabular}{lcccc}
\hline & $\begin{array}{c}\text { Number of } \\
\text { firms receiving } \\
\text { VC funding }\end{array}$ & $\begin{array}{c}\text { Success by } \\
\text { IPO (in \%) }\end{array}$ & $\begin{array}{c}\text { Success by } \\
\text { Acquisition or } \\
\text { Merger (in \%) }\end{array}$ & $\begin{array}{c}\text { Overall } \\
\text { Success } \\
\text { (in \%) }\end{array}$ \\
\hline United States & 34,088 & 13.43 & 21.94 & 41.40 \\
EU-15 & 17,909 & 7.70 & 10.34 & 38.33 \\
EU-15 (excl. Greece \& Luxembourg) & 17,775 & 7.66 & 10.40 & 38.41 \\
\hline
\end{tabular}

Table I indicates that between 1985 and 2008 nearly twice as many firms received VC funding in the U.S. alone then in the whole EU-15 area. For both the U.S. and the Euro Area, exit via merger and acquisition (M\&A) is more likely than exit via IPO. As documented in previous studies (Black and Gilson (1998), Murray and Marriott (1998), and Bottazi and Da Rin (2002)), VC has produced more successful exits in the U.S. then in Europe. Particularly, U.S. firms outperform EU-15 firms by a 2-to-1 ratio when it comes to both exits by IPO, and via M\&A. However, once we include leveraged buy-outs (LBOs) as a successful exit, the difference between Europe and the US shrinks considerably. But LBOs are not necessarily a desirable outcome. 
Table II displays the comparison of VC investments and success rates between the U.S. and Europe separated for infant and mature firms.

\section{Table II}

\section{Comparison between the U.S. and EU-15: Venture Capital and Success by Infant} and Mature Firms

Notes: Success by Infant Firms is computed as the number of start-up and seed, and early-stage firms who successfully exited by going public, merger and acquisition, or leveraged buy-outs, divided by the total number of start-up and seed, and early-stage firms which received venture capital funding. Success by Mature Firms is computed as the number of established firms who successfully exited by going public, merger/acquisition, or leveraged buy-outs, divided by the total number of established firms, which received venture capital funding. For both measures, the rates were computed considering all transactions between 1985 and 2008, by industry and country, and were multiplied by a factor of 100 .

\begin{tabular}{lcccc}
\hline & $\begin{array}{c}\text { Ex-ante ratio } \\
\text { (mature firms } \\
\text { to early stage) }\end{array}$ & $\begin{array}{c}\text { Success by } \\
\text { infant firms } \\
\text { (in \%) }\end{array}$ & $\begin{array}{c}\text { Success by } \\
\text { mature firms } \\
\text { (in \%) }\end{array}$ & $\begin{array}{c}\text { Ex-post ratio } \\
\text { (mature firms } \\
\text { to early stage) }\end{array}$ \\
\hline United States & 1.07 & 34.50 & 47.82 & 1.49 \\
EU-15 & 2.74 & 15.70 & 46.72 & 8.14 \\
EU-15 (excl. Greece \& Luxembourg) & 2.73 & 15.63 & 46.64 & 8.15 \\
\hline
\end{tabular}

For the U.S., nearly an equal number of mature vis-à-vis infant firms were financed. On the contrary, for the EU-15, eight out of every 11 firms financed were mature firms. Moreover, Table II indicates that success rates are drastically different. Consistent with previous findings in the literature early stage and seed and start-up firms in Europe largely underperform in comparison to their counterparts in the U.S. (see Murray and Marriott (1998) for evidence between 1991 and 1997, and Hege, Palomino and Schwienbacher (2009) as well as Raade and Dantas Machado (2008) for more recent evidence), while mature VC-backed firms have close to 50 percent probability of success both in Europe and the U.S.

These two above observations combined make for an overwhelming outcome: The ratio of successful mature firms to successful infant firms in Europe is over 8-to-1, while it is less than 1.5 in the U.S. Therefore, the difference one needs to focus on is not 
only why VC financing is more successful in the U.S. but why start-up/seed and earlystage firms are relatively unsuccessful in Europe.

Before we get to analyze these substantial differences with the help of regression analysis, we first investigate whether there are significant differences in performance between the six different industries. From here on forth, we exclude Greece and Luxembourg from the analysis, since for some industries there were no transactions registered in the case of these two countries. As can be seen from Tables I and II, the size effects in terms of total firm count and average success rates from excluding both countries are negligible.

Our empirical findings in Table III prove that the aggregate results are also found at an industry-by-industry summary analysis, with just a few exceptions. The U.S. outperforms Europe in success by acquisition (significantly for all six industries), and in success by IPO (albeit it is only significant for medical, health and life sciences as well as for non-high technology and other). Moreover, the U.S. outperforms Europe in success by early-stage firms (significantly for all industries), and is similar to Europe in success by mature firms (no significant differences for any of the industries).

Table III also indicates that exit by acquisition has a higher rate of success than exit by IPO, except for VC-backed biotech firms. Exit by IPO, as documented by Gompers and Lerner (1998), provides significantly higher returns when compared to other types of exit. The observation that the biotech sector is the "best" performer comes to no surprise - as of the last decade, this sector has been identified as one of the thriving new industries in the U.S. (see Gordon (2002) as well as Guo, Lev and Zhou (2005)). Similarly, in the case of Europe, its characteristics confirm it as one of the most dynamic industries; according to Popov and Roosenboom (2009), as of 2005, 55\% of biotech companies in Europe were less than 5 years old; the rate of new business incorporation was $14 \%$ on average, $44 \%$ of biotech employees in Europe have been actively involved in research and development (R\&D); and the industry spent 7.5 billion Euro on $R \& D$ in 2004 alone, making it one of the most R\&D intensive sectors in Europe. 


\section{Table III}

\section{Comparison between the U.S. and EU-15: Industry-by-Industry}

Notes: Success by IPO and Success by Acquisition or Merger are computed as the number of firms who successfully exited via IPO (merging with or being acquired by other firms, respectively) divided by the total number of firms receiving venture capital funding. Success by Infant Firms is computed as the number of start-up and seed, and early-stage firms who experienced overall success, divided by the total number of start-up and seed, and early-stage firms which received venture capital funding. Success by Mature Firms is computed as the number of established firms who experienced overall success, divided by the total number of established firms, which received venture capital funding. For all measures, the rates were computed considering all transactions between 1985 and 2008, by industry and country, and were multiplied by a factor of $100 . * *, * *$, and $*$ determine significance at the $1 \%, 5 \%$, and $10 \%$ level, respectively.

\begin{tabular}{|c|c|c|c|c|}
\hline & $\begin{array}{l}\text { Success by } \\
\text { IPO (in \%) }\end{array}$ & $\begin{array}{c}\text { Success by } \\
\text { Acquisition or } \\
\text { Merger (in \%) }\end{array}$ & $\begin{array}{l}\text { Success by } \\
\text { infant firms } \\
\text { (in } \%)\end{array}$ & $\begin{array}{l}\text { Success by } \\
\text { mature firms } \\
\quad(\text { in } \%)\end{array}$ \\
\hline \multicolumn{5}{|l|}{ Computer Hardware and Software } \\
\hline United States & 9.43 & 27.21 & 35.34 & 44.69 \\
\hline EU-15 (excl. Greece \& Luxembourg) & 7.49 & 11.68 & 15.77 & 34.81 \\
\hline Test of difference in means (significance) & & $* * *$ & $* * *$ & \\
\hline \multicolumn{5}{|l|}{ Semi- Conductors and Other Electronics } \\
\hline United States & 13.72 & 24.35 & 35.61 & 52.55 \\
\hline EU-15 (excl. Greece \& Luxembourg) & 7.88 & 10.72 & 13.26 & 45.58 \\
\hline Test of difference in means (significance) & & $* *$ & $* *$ & \\
\hline \multicolumn{5}{|l|}{ Biotechnology } \\
\hline United States & 22.14 & 16.06 & 35.74 & 51.00 \\
\hline EU-15 (excl. Greece \& Luxembourg) & 11.54 & 9.08 & 19.96 & 34.81 \\
\hline Test of difference in means (significance) & & * & $*$ & \\
\hline \multicolumn{5}{|l|}{ Medical / Health / Life Sciences } \\
\hline United States & 17.89 & 19.11 & 34.30 & 50.84 \\
\hline EU-15 (excl. Greece \& Luxembourg) & 10.49 & 9.62 & 16.02 & 48.66 \\
\hline Test of difference in means (significance) & * & $* *$ & $*$ & \\
\hline \multicolumn{5}{|l|}{ Communications and Media } \\
\hline United States & 13.10 & 27.47 & 38.30 & 48.91 \\
\hline EU-15 (excl. Greece \& Luxembourg) & 8.32 & 14.02 & 20.20 & 39.95 \\
\hline Test of difference in means (significance) & & $* *$ & $* * *$ & \\
\hline \multicolumn{5}{|l|}{ Non-High Technology / Other } \\
\hline United States & 14.74 & 16.54 & 27.28 & 47.95 \\
\hline EU-15 (excl. Greece \& Luxembourg) & 6.96 & 9.50 & 11.75 & 50.72 \\
\hline Test of difference in means (significance) & $* * *$ & $* * *$ & $* * *$ & \\
\hline
\end{tabular}


It is therefore worthwhile asking: Can we identify any other success story - other than venture capital in the biotech industry? Or is it the case, as this first overview suggests, that differences in success rates are mainly linked to the Europe-U.S. differences, rather than industry-specific characteristics? We attempt to find some answers to these questions in our next section, by conducting a more in-depth regression analysis in order to control for other explanatory variables.

\section{Regression Analysis}

We empirically investigate in the following which factors are associated with successful $\mathrm{VC}$ investments by means of multi-variable analysis. We begin by providing a brief discussion as to which indicators serve as a good proxy for determinants we expect to play a significant role in enhancing the likelihood of a successful exit by a VC-backed firm.

\section{Venture Capital Investment by Industry Group}

First of all, it is important to distinguish between funds raised and funds invested. A venture capital fund will raise resources each year; however they may not necessarily invest those funds in the same year. VC funds are actively managing current portfolio companies until the proper exit time and may not be ready to take on a new investment until a current company has exited because of management availability. Likewise, funds raised may be inaccurate as a proxy because many times it is simply a roll-over process of funds from one project to the next. To explain, when a $\mathrm{VC}$ fund exits a portfolio company, these funds are then returned to their original investors, who many times become repeat clients to the $\mathrm{VC}$ fund and reinvest their desired level of capital back into the fund, which then represents the way capital is recycled in a VC fund. Another reason why funds raised may not show a logical pattern to actual investment is that VC funds may have not found what they consider to be high potential investments, and may decide to wait and keep the funds sitting until an opportune venture is found or inquires directly by the fund for $\mathrm{VC}$ funding assistance.

In contrast, data on $\mathrm{VC}$ disbursements is exactly the capital given a designation into a venture company, and best represents the activity of $\mathrm{VC}$ on the supply side 
regarding investment level of funds. This variable can best identify how much capital has been put into venture capital-backed companies in each industry and country. It is more interesting to see whether one industry or country is spending more or less in relative terms, and moreover how that has played a role in the ability of each portfolio company to reach exit stage.

For our regression analysis we employ the average investment per firm (in millions of Euro) per industry and country, over the period 1985-2008. A priori, one would expect that, the larger the amount of resources devoted to a representative firm belonging to a particular industry, the more likely it will be that this representative firm has a successful exit.

\section{Gross Domestic Product}

A high level of aggregate economic growth might indicate favorable entrepreneurial conditions; as periods of increased GDP might indicate that possibilities to commercialize technological innovations are increased (see Gompers and Lerner (1998) as well as and Jeng and Wells (2000)). In our regressions we need therefore to control for aggregate economic activity. Moreover, since we are using averages over time and not a year-by-year analysis, we opt for using average GDP per capita (in thousands of Euro), between 1985 and 2008, for each of the countries of interest. We would expect in general that higher GDP per capita should be associated with a higher likelihood of a successful VC project. Since several studies that use cross-country data also control for real GDP growth as a determinant of VC investment (Jeng and Wells (2000), Gomes Santana Felix, Gulamhussen and Pacheco Pires (2007), among others), we run a separate set of regressions employing real growth instead of GDP per capita. The results, which are presented in Tables A3 and A4 in the appendix, suggest that our main findings are robust to the use of this alternative measure of economic activity.

\section{$\underline{\text { Research and Development Expenditures }}$}

Venture capital investments are high-risk, high-reward projects, which makes them substitutable with R\&D investments. Thus, an increase in domestic expenditure on R\&D would imply a greater supply of funds available for $\mathrm{VC}$ and also demand for similar high- 
tech, high-risk companies. When R\&D is better funded, the chances of technological and other advanced science opportunities should increase and may dually lead to more VC ventures. R\&D data are broken down into the following sources of funding: business enterprise, government, and their total.

In expectation, times in which investments in $R \& D$ are higher might indicate higher technological or innovative opportunities. Besides the idea that R\&D spending might capture demand effects over time, it might also capture demand effects across countries. In this understanding, countries with higher levels of $R \& D$ spending might contain a higher number of entrepreneurs with potentially fruitful ideas. This effect has been described by Gompers and Lerner (1998) who show for the U.S. that states with higher levels of both academic and corporate R\&D spending also have higher levels of VC financing activity.

Our analysis controls therefore for aggregate $R \& D$ per capita, also for the period comprising 1985-2008, for each of the countries in our sample. All other things equal, a larger amount of funds devoted for R\&D would be associated with higher technological or innovative opportunities, and therefore, higher likelihood of success of VC-financed projects.

\section{$\underline{\text { Patents }}$}

Higher levels of patent applications could be used to indicate higher levels of technological opportunities, and thus VC activity. The data seeks to capture how many applications are made by each country, regardless of whether the applicant was domiciled in that nation or not. Kortum and Lerner (2000) show that venture capital has a higher propensity to generate patent applications than does R\&D spending. In relation thereto, if patent applications are a proxy for innovation, periods or countries with relatively more patent applications might indicate higher technological opportunities. On a per country basis, higher patenting activity might also indicate a greater willingness to commercialize innovations and to protect ones inventions. 


\section{$\underline{\text { Industry-specific variables }}$}

Our baseline specification for the regression analyses is to model our alternative measures of success as a linear function of average investment per firm (in millions of Euro); GDP per capita and $R \& D$ per capita (both measured in thousands of Euro); and the number of patents (per one-thousand inhabitants). We do so with a sample of 13 European countries (i.e. EU-15 excluding Greece and Luxembourg, as a result of the above-mentioned data limitations), and across the 6 industries of interest. Given the documented differences in performance of VC-funded firms in the U.S. and Europe, we run the regressions with and without the U.S., to verify if the main results at the industry level still apply.

To our baseline specifications we also add industry-specific dummy variables to test whether there are significant differences between industries in regards to the rates of success. Specifically, we will use the non-high tech sector as the benchmark for comparison. This broad sector comprises firms of the following industries: business services, agricultural, forestry, financial services, utilities, manufacturing, transportation, construction, chemicals and materials, pollution and recycling, industrial equipment, oil and gas exploration, consumer products, entertainment and leisure, and food and beverage; and it represents $36 \%$ and $54 \%$ of all firms receiving VC funding for the U.S. and the EU-15, respectively.

In a first step, we differentiate between two successful exit strategies: exit via IPO and exit via M\&A. In the second step, we run separate regressions for infant and mature firms. Table IV shows the regression results for all firms with an IPO as a successful exit strategy.

Table IV shows that in case of a successful exit via IPO, the average investment is positive and significant for the entire period. All other things equal, a higher level of VC funding to a particular industry makes this industry more likely to successfully go public. We also see that for exit via IPO the level of GDP per capita matters: it is positive and significant at $5 \%$ for all specifications. Interestingly and contrary to our expectations and previous studies, the level of R\&D investments is not significant. 


\section{Table IV}

\section{Success 1: Exit via IPO}

Notes: Successful Exit via IPO is computed as the number of firms who successfully exited by going public, divided by the total number of firms receiving venture capital funding, between 1985 and 2008, by industry and country, multiplied by a factor of 100. Average investment per firm is measured in millions of Euro. GDP per capita and $R \& D$ per capita are measured in thousands of Euro. The number of patents is per 1,000 inhabitants. Robust standard errors are in parentheses. $* * *, *$, and $*$ determine significance at the $1 \%, 5 \%$, and $10 \%$ levels, respectively.

\begin{tabular}{|c|c|c|c|c|}
\hline & $\begin{array}{c}\text { Baseline } \\
\text { (all countries) }\end{array}$ & $\begin{array}{c}\text { Baseline } \\
\text { (excl. U.S.) }\end{array}$ & $\begin{array}{l}\text { Industry-specific } \\
\text { (all countries) }\end{array}$ & $\begin{array}{l}\text { Industry-specific } \\
\text { (excl. U.S.) }\end{array}$ \\
\hline Average investment per firm & $\begin{array}{c}0.330 * * * \\
(0.076)\end{array}$ & $\begin{array}{l}0.327 * * * \\
(0.102)\end{array}$ & $\begin{array}{c}0.307 * * * \\
(0.069)\end{array}$ & $\begin{array}{l}0.288 * * * \\
(0.097)\end{array}$ \\
\hline GDP per capita & $\begin{array}{c}0.225 * * \\
(0.108)\end{array}$ & $\begin{array}{c}0.231 * * \\
(0.108)\end{array}$ & $\begin{array}{c}0.224 * * \\
(0.109)\end{array}$ & $\begin{array}{c}0.233 * * \\
(0.109)\end{array}$ \\
\hline R\&D per capita & $\begin{array}{c}5.357 \\
(4.769)\end{array}$ & $\begin{array}{c}5.275 \\
(4.674)\end{array}$ & $\begin{array}{c}5.801 \\
(4.610)\end{array}$ & $\begin{array}{c}5.971 \\
(4.659)\end{array}$ \\
\hline Patents & $\begin{array}{l}-0.631 \\
(0.437)\end{array}$ & $\begin{array}{c}-0.724 * \\
(0.433)\end{array}$ & $\begin{array}{l}-0.644 \\
(0.457)\end{array}$ & $\begin{array}{c}-0.779 * \\
(0.473)\end{array}$ \\
\hline Computer Hardware and Software & & & $\begin{array}{c}0.162 \\
(0.888)\end{array}$ & $\begin{array}{c}0.403 \\
(0.935)\end{array}$ \\
\hline Semi-Conductors / Other Electronics & & & $\begin{array}{l}-0.670 \\
(1.171)\end{array}$ & $\begin{array}{l}-0.577 \\
(1.262)\end{array}$ \\
\hline Biotechnology & & & $\begin{array}{l}3.079 * \\
(1.749)\end{array}$ & $\begin{array}{l}2.677 \\
(1.780)\end{array}$ \\
\hline Medical / Health / Life Sciences & & & $\begin{array}{l}2.269^{*} \\
(1.208)\end{array}$ & $\begin{array}{l}2.110^{*} \\
(1.240)\end{array}$ \\
\hline Communications and Media & & & $\begin{array}{c}0.705 \\
(1.501)\end{array}$ & $\begin{array}{c}1.173 \\
(1.563)\end{array}$ \\
\hline Adjusted R-squared & 0.361 & 0.283 & 0.428 & 0.341 \\
\hline No. of Observations & 84 & 78 & 84 & 78 \\
\hline
\end{tabular}


Table IV indicates that if we exclude the U.S. from the sample, patents become marginally significant, albeit with a negative sign. With respect to the non high-tech sector, VC investment in biotech is more likely to result in an IPO. It contains a 3 percent higher success rate via an IPO, after controlling for other variables. It is significant with the U.S., but once we exclude the U.S. from our sample, the coefficient becomes smaller and no longer significant at the $10 \%$ level.

Firms receiving VC funds in the medical, health, and life sciences industry are also more likely to exit via IPO (2 percent higher success rate), while the effect remains similar if we exclude the U.S. from the sample. Finally, all other industries do not significantly differ from the non high-tech sector.

Table V shows that in the case of a successful exit via a merger or an acquisition, the average investment is again positive and significant. This result holds for all specifications and all measures of success. It is also interesting to see that none of the country-specific control variables help in explaining a more successful exit via M\&A. Excluding the U.S. from the analysis does not affect any of the results. However, it does lower considerably the explanatory power and it cuts in almost half the coefficient on average investment.

VC-backed firms in the Computer Hardware and Software industry are more likely to exit via merger and acquisition (3.2 percent) than our control group of non hightech and other firms. After controlling for funds and other variables, this finding still holds. Dropping the U.S. from our sample reduces the coefficient to 2.2 percent, but it is still significant at the 5\% level. Firms in the Communications and Media industry are also more likely to exit via M\&A: 5.3 to 5.4 percent, i.e. the results prove to be robust to either with or without the U.S. On the other hand, biotech appears to be the opposite story: it is less likely to exit a VC-backed biotech firm via M\&A in comparison to the non high-tech sector. Firms of the other two industries, Semi-conductors and other electronics as well as medical, health, and life sciences, show no significantly different likelihood of a successful exit. 


\section{Table V}

\section{Success 2: Exit via Acquisition or Merger}

Notes: Successful Exit via Acquisition or Merger is computed as the number of firms who successfully exited by merging with or being acquired by other firms, divided by the total number of firms receiving venture capital funding, between 1985 and 2008, by industry and country, multiplied by a factor of 100 . Average investment per firm is measured in millions of Euro. GDP per capita and $R \& D$ per capita are measured in thousands of Euro. The number of patents is per 1,000 inhabitants. Robust standard errors are in parentheses. $* * *, *$, and $*$ determine significance at the $1 \%, 5 \%$, and $10 \%$ levels, respectively.

\begin{tabular}{|c|c|c|c|c|}
\hline & $\begin{array}{c}\text { Baseline } \\
\text { (all countries) }\end{array}$ & $\begin{array}{l}\text { Baseline } \\
\text { (excl. U.S.) }\end{array}$ & $\begin{array}{l}\text { Industry-specific } \\
\text { (all countries) }\end{array}$ & $\begin{array}{l}\text { Industry-specific } \\
\quad \text { (excl. U.S.) }\end{array}$ \\
\hline Average investment per firm & $\begin{array}{l}0.355 * * * \\
(0.078)\end{array}$ & $\begin{array}{c}0.167 * * \\
(0.069)\end{array}$ & $\begin{array}{c}0.374 * * * \\
(0.077)\end{array}$ & $\begin{array}{l}0.215 * * * \\
(0.076)\end{array}$ \\
\hline GDP per capita & $\begin{array}{c}0.089 \\
(0.216)\end{array}$ & $\begin{array}{c}0.120 \\
(0.210)\end{array}$ & $\begin{array}{c}0.089 \\
(0.179)\end{array}$ & $\begin{array}{c}0.118 \\
(0.172)\end{array}$ \\
\hline R\&D per capita & $\begin{array}{l}-0.359 \\
(5.980)\end{array}$ & $\begin{array}{c}2.513 \\
(5.529)\end{array}$ & $\begin{array}{l}-0.729 \\
(4.264)\end{array}$ & $\begin{array}{c}1.647 \\
(4.354)\end{array}$ \\
\hline Patents & $\begin{array}{c}0.273 \\
(0.441)\end{array}$ & $\begin{array}{l}-0.309 \\
(0.417)\end{array}$ & $\begin{array}{c}0.284 \\
(0.408)\end{array}$ & $\begin{array}{l}-0.240 \\
(0.419)\end{array}$ \\
\hline Computer Hardware and Software & & & $\begin{array}{l}3.153 * * * \\
(1.196)\end{array}$ & $\begin{array}{c}2.194 * * \\
(0.936)\end{array}$ \\
\hline Semi-Conductors / Other Electronics & & & $\begin{array}{c}1.912 \\
(1.692)\end{array}$ & $\begin{array}{c}1.638 \\
(1.770)\end{array}$ \\
\hline Biotechnology & & & $\begin{array}{c}-2.453 * * * \\
(0.960)\end{array}$ & $\begin{array}{c}-2.328 * * \\
(1.022)\end{array}$ \\
\hline Medical / Health / Life Sciences & & & $\begin{array}{l}-1.491 \\
(1.315)\end{array}$ & $\begin{array}{l}-1.648 \\
(1.379)\end{array}$ \\
\hline Communications and Media & & & $\begin{array}{c}5.342 * * * \\
(1.883)\end{array}$ & $\begin{array}{c}5.448 * * * \\
(1.868)\end{array}$ \\
\hline Adjusted R-squared & 0.265 & 0.068 & 0.472 & 0.338 \\
\hline No. of Observations & 84 & 78 & 84 & 78 \\
\hline
\end{tabular}


In the following we also investigate whether the life-cycle of the VC-backed firms might play a pivotal role in the determination of successful exits. Table VI presents our findings of successful exits of infants firms.

Table VI indicates that the average investment has a positive and significant correlation with success of start-up/seed and early-stage firms. Interestingly, neither R\&D, nor GDP per capita contribute towards explaining a more successful exit of startup/seed and early-stage firms. Patents have a negative and significant correlation with success for infant firms - only when excluding the U.S. from the data. All industries (except Semi-conductors / other electronics) exhibit positive and significantly higher likelihood of success of start-up/seed and early-stage firms, when compared to the non high-tech sector. The empirical findings in Table VI also show that excluding the U.S. from the regression analysis does not affect any of the results.

Table VII presents our empirical findings for the regressions analysis of successful exits of mature firms. The results show that average investment is again positive and significant for all specifications. The level of R\&D investments only matters when controlling for industry-specific effects and when the U.S. is included in the sample. Moreover, GDP per capita and patents help in explaining a more successful exit of mature firms. As expected, our empirical findings in Table VII quite mirror the image of the previous results of infant firms. All industries are less likely to experience a successful exit by mature firms, when compared to the non high-tech sector. In the case of the medical, health, and life-science industry as well as for communications and media, the coefficients are negative, but not statistically significant. 


\section{Table VI}

\section{Successful Exit of Infant Firms}

Notes: Successful Exit of Infant Firms is computed as the number of start-up and seed, and early-stage firms who successfully exited by going public, merger, acquisition, or leveraged buy-outs, divided by the total number of start-up and seed, and early-stage firms which received venture capital funding, between 1985 and 2008, by industry and country; multiplied by a factor of 100 . Average investment per firm is measured in millions of Euro. GDP per capita and $R \& D$ per capita are measured in thousands of Euro. Robust standard errors are in parentheses. $* * *, * *$, and $*$ determine significance at the $1 \%, 5 \%$, and $10 \%$ levels, respectively.

\begin{tabular}{|c|c|c|c|c|}
\hline & $\begin{array}{c}\text { Baseline } \\
\text { (all countries) }\end{array}$ & $\begin{array}{c}\text { Baseline } \\
\text { (excl. U.S.) }\end{array}$ & $\begin{array}{l}\text { Industry-specific } \\
\text { (all countries) }\end{array}$ & $\begin{array}{l}\text { Industry-specific } \\
\quad \text { (excl. U.S.) }\end{array}$ \\
\hline Average investment per firm & $\begin{array}{l}0.756^{* * * *} \\
\quad(0.124)\end{array}$ & $\begin{array}{c}0.530 * * * \\
(0.141)\end{array}$ & $\begin{array}{c}0.712 * * * \\
(0.140)\end{array}$ & $\begin{array}{c}0.463 * * * \\
(0.164)\end{array}$ \\
\hline GDP per capita & $\begin{array}{c}0.044 \\
(0.319)\end{array}$ & $\begin{array}{c}0.088 \\
(0.314)\end{array}$ & $\begin{array}{c}0.044 \\
(0.306)\end{array}$ & $\begin{array}{c}0.091 \\
(0.298)\end{array}$ \\
\hline R\&D per capita & $\begin{array}{c}6.693 \\
(7.644)\end{array}$ & $\begin{array}{l}10.004 \\
(7.971)\end{array}$ & $\begin{array}{c}7.539 \\
(7.380)\end{array}$ & $\begin{array}{l}11.198 \\
(7.778)\end{array}$ \\
\hline Patents & $\begin{array}{l}-0.527 \\
(0.679)\end{array}$ & $\begin{array}{c}-1.327^{*} \\
(0.795)\end{array}$ & $\begin{array}{l}-0.553 \\
(0.641)\end{array}$ & $\begin{array}{c}-1.422 * \\
(0.728)\end{array}$ \\
\hline Computer Hardware and Software & & & $\begin{array}{c}6.393 * * * \\
(1.958)\end{array}$ & $\begin{array}{l}5.601 * * * \\
(1.978)\end{array}$ \\
\hline Semi-Conductors / Other Electronics & & & $\begin{array}{c}4.853 \\
(3.355)\end{array}$ & $\begin{array}{l}4.888 \\
(3.542)\end{array}$ \\
\hline Biotechnology & & & $\begin{array}{c}6.988 * * * \\
(2.415)\end{array}$ & $\begin{array}{l}7.260 * * * \\
(2.720)\end{array}$ \\
\hline Medical / Health / Life Sciences & & & $\begin{array}{l}5.857^{*} \\
(3.229)\end{array}$ & $\begin{array}{l}5.960^{*} \\
(3.260)\end{array}$ \\
\hline Communications and Media & & & $\begin{array}{l}10.896 * * * \\
(2.413)\end{array}$ & $\begin{array}{l}11.834 * * * \\
(2.463)\end{array}$ \\
\hline Adjusted R-squared & 0.309 & 0.142 & 0.405 & 0.285 \\
\hline No. of Observations & 84 & 78 & 84 & 78 \\
\hline
\end{tabular}




\section{Table VII \\ Successful Exit of Mature Firms}

Notes: Successful Exit of Mature Firms is computed as the number of established firms who successfully exited by going public, merger/acquisition, or leveraged buy-outs, divided by the total number of established firms which received venture capital funding, between 1985 and 2008 , by industry and country; multiplied by a factor of 100 . Average investment per firm is measured in millions of Euro. GDP per capita and $R \& D$ per capita are measured in thousands of Euro. The number of patents is per 1,000 inhabitants. Robust standard errors are in parentheses. $* * *, * *$, and $*$ determines significance at the $1 \%, 5 \%$, and $10 \%$ level, respectively.

\begin{tabular}{|c|c|c|c|c|}
\hline & $\begin{array}{c}\text { Baseline } \\
\text { (all countries) }\end{array}$ & $\begin{array}{l}\text { Baseline } \\
\text { (excl. U.S.) }\end{array}$ & $\begin{array}{l}\text { Industry-specific } \\
\text { (all countries) }\end{array}$ & $\begin{array}{l}\text { Industry-specific } \\
\text { (excl. U.S.) }\end{array}$ \\
\hline Average investment per firm & $\begin{array}{c}0.671 * * * \\
(0.155)\end{array}$ & $\begin{array}{c}0.776 * * * \\
(0.233)\end{array}$ & $\begin{array}{c}0.672 * * * \\
(0.169)\end{array}$ & $\begin{array}{c}0.829 * * * \\
(0.276)\end{array}$ \\
\hline GDP per capita & $\begin{array}{l}-0.261 \\
(0.430)\end{array}$ & $\begin{array}{l}-0.271 \\
(0.426)\end{array}$ & $\begin{array}{l}-0.261 \\
(0.388)\end{array}$ & $\begin{array}{l}-0.274 \\
(0.376)\end{array}$ \\
\hline R\&D per capita & $\begin{array}{l}16.246 \\
(11.905)\end{array}$ & $\begin{array}{c}14.489 \\
(12.177)\end{array}$ & $\begin{array}{c}16.239 * \\
(8.687)\end{array}$ & $\begin{array}{l}13.526 \\
(5.687)\end{array}$ \\
\hline Patents & $\begin{array}{l}-0.706 \\
(1.175)\end{array}$ & $\begin{array}{l}-0.484 \\
(1.255)\end{array}$ & $\begin{array}{l}-0.706 \\
(0.884)\end{array}$ & $\begin{array}{l}-0.407 \\
(0.919)\end{array}$ \\
\hline Computer Hardware and Software & & & $\begin{array}{c}-12.053 * * * \\
(2.619)\end{array}$ & $\begin{array}{c}-12.880 * * * \\
(2.660)\end{array}$ \\
\hline Semi-Conductors / Other Electronics & & & $\begin{array}{c}-6.590^{*} \\
(3.833)\end{array}$ & $\begin{array}{l}-7.453^{*} \\
(3.968)\end{array}$ \\
\hline Biotechnology & & & $\begin{array}{c}-14.779 * * * \\
(5.181)\end{array}$ & $\begin{array}{c}-16.834 * * * \\
(5.586)\end{array}$ \\
\hline Medical / Health / Life Sciences & & & $\begin{array}{l}-4.722 \\
(3.717)\end{array}$ & $\begin{array}{l}-5.899 \\
(3.942)\end{array}$ \\
\hline Communications and Media & & & $\begin{array}{l}-5.282 \\
(3.593)\end{array}$ & $\begin{array}{l}-5.409 \\
(3.765)\end{array}$ \\
\hline Adjusted R-squared & 0.181 & 0.142 & 0.325 & 0.317 \\
\hline No. of Observations & 84 & 78 & 84 & 78 \\
\hline
\end{tabular}


Summarizing our main results we find that in all specifications, the average amount of funding VC-backed firms receive is a robust and consistent predictor of the likelihood of success. This holds for any type of exit (whether via IPO, M\&A, or overall success) but also for when we separate firms into by the stage in which initial investment takes places (infant and mature).

More interestingly, different industries do exhibit different patterns in regards to their rate of success: firms in the biotech and the medical, health, and life science industry tend to be significantly more likely to have a successful exit via IPO, while firms in the computer industry and communications and media are more prone to exit via merger or acquisition.

\section{Conclusions}

Success in VC-funded firms clearly depends on a wide array of factors, many of them quite specific. The contribution of this paper consists in attempting to identify general conditions under which enterprises belonging to certain industries in distinct countries can achieve a higher likelihood of a desirable exit.

Our findings allow us to argue that differences in the rates of success may only partly be due to the intrinsic differences between the European and U.S. VC experiences. Industry-specific characteristics also play an important role - in particular, our results suggest that the relatively higher success rate found in VC-funded biotech firms, for instance, may be mostly due to the intrinsic dynamic nature of this sector, and less to where the firms are located and where the funds come from.

We also observe - confirming the findings of previous studies - that differences in the stage at which firms received $\mathrm{VC}$ funding tends to be a crucial determinant of success - mainly for European countries.

Finally, we recognize that this constitutes only a first step towards explaining differences in rates of success and types of exits. Other factors, such as the degree of experience of venture capital organizations (Gompers et al, 2008), and other industryspecific characteristics, need to be controlled for to draw more definite conclusions. These and other extensions are on our sights for future research. 


\section{References}

Black, Bernard S. and Ronald J. Gilson (1998). "Venture Capital and the Structure of Capital Markets- Bank versus Stock Markets”, Journal of Financial Economics, 47, pp. 243-277.

Botazzi, Laura and Marco Da Rin (2002). "Venture Capital in Europe and the Financing of Innovative Companies", Economic Policy, 17:4, pp. 229-270.

Cochrane, John (2005). "The Risk and Return of Venture Capital”, Journal of Financial Economics, 75:1, pp. 3-52.

Cumming, Douglas and Jeffrey G. MacIntosh (2003). "A Cross-Country Comparison of Full and Partial Venture Capital Exits", Journal of Banking and Finance, 27:3, pp. $511-548$

Gomes Santana Felix, Elisabete, Mohamed A. Gulamhussen, and Cesaltina Pacheco Pires (2007). "The Determinants of Venture Capital in Europe - Evidence Across Countries”, CEFAGE Working Paper 2007/01.

Gompers, Paul A. and Josh Lerner (1998). "What Drives Venture Capital Fundraising?”, Brooking Papers on Economic Activity (Microeconomics), pp. 149-180.

Gompers, Paul A. and Josh Lerner (2001). “The Venture Capital Revolution”, Journal of Economic Perspectives, 15:2, pp. 145-168.

Gompers, Paul A., Anna Kovner, Josh Lerner and David Scharfstein (2008). "Venture Capital Investment Cycles: The Impact of Public Markets", Journal of Financial Economics, 87:1, pp. 1-23.

Gordon, Robert J. (2002). "Technology and Economic Performance in the American Economy", NBER Working Paper No. 8771.

Guo, Re J., Baruch I. Lev and Nan Zhou (2005). "The Valuation of Biotech IPOs", Journal of Accounting, Auditing and Finance, 20:4, pp. 423-459.

Hege, Ulrich, Frederic Palomino and Armin Schwienbacher (2009). "Venture Capital Performance: The Disparity between Europe and the United States", Revue Finance, $30: 1$, pp. $7-50$. 
Jeng, Leslie A. and Philippe C. Wells (2000). "The Determinants of Venture Capital Funding: Evidence across Countries", Journal of Corporate Finance, 6:3, pp. 241289.

Kortum, Samuel and Josh Lerner (2000). “Assessing the Contribution of Venture Capital to Innovation", RAND Journal of Economics, 31, pp. 674-692.

Murray, Gordon C. and Richard Marriott (1998). "Why has the Investment Performance of Technology-Specialist, European Venture Capital Funds been so Poor?”, Research Policy, 27, pp. 947-976.

Popov, Alexander and Peter Roosenboom (2009). "Does Private Equity Investment Spur Innovation? Evidence from Europe", ECB Working Paper No. 1063.

Raade, Kristiina and Catarina Dantas Machado (2008). "Recent Developments in the European Private Equity Markets”, European Commission, Economic Paper No. 319. 


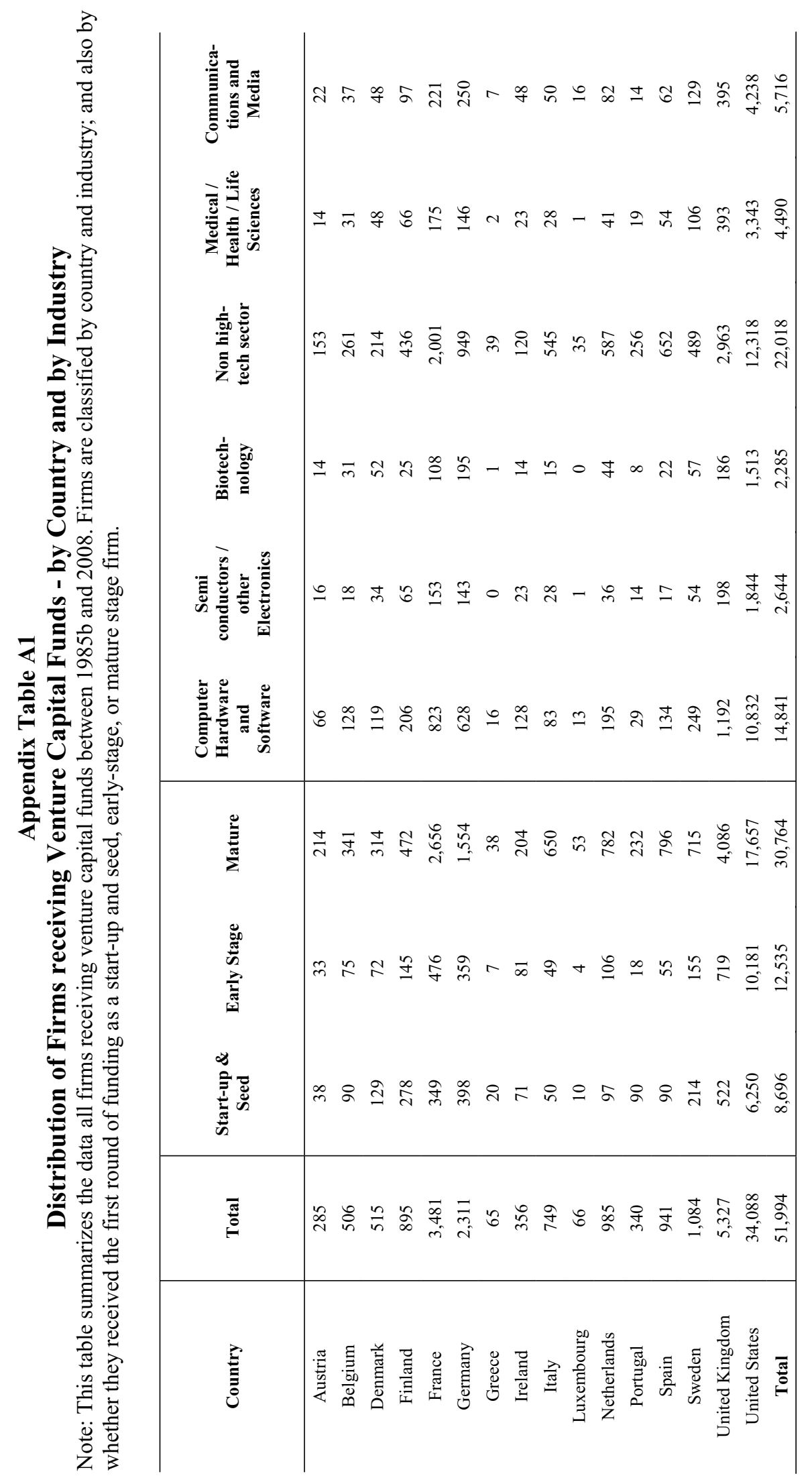




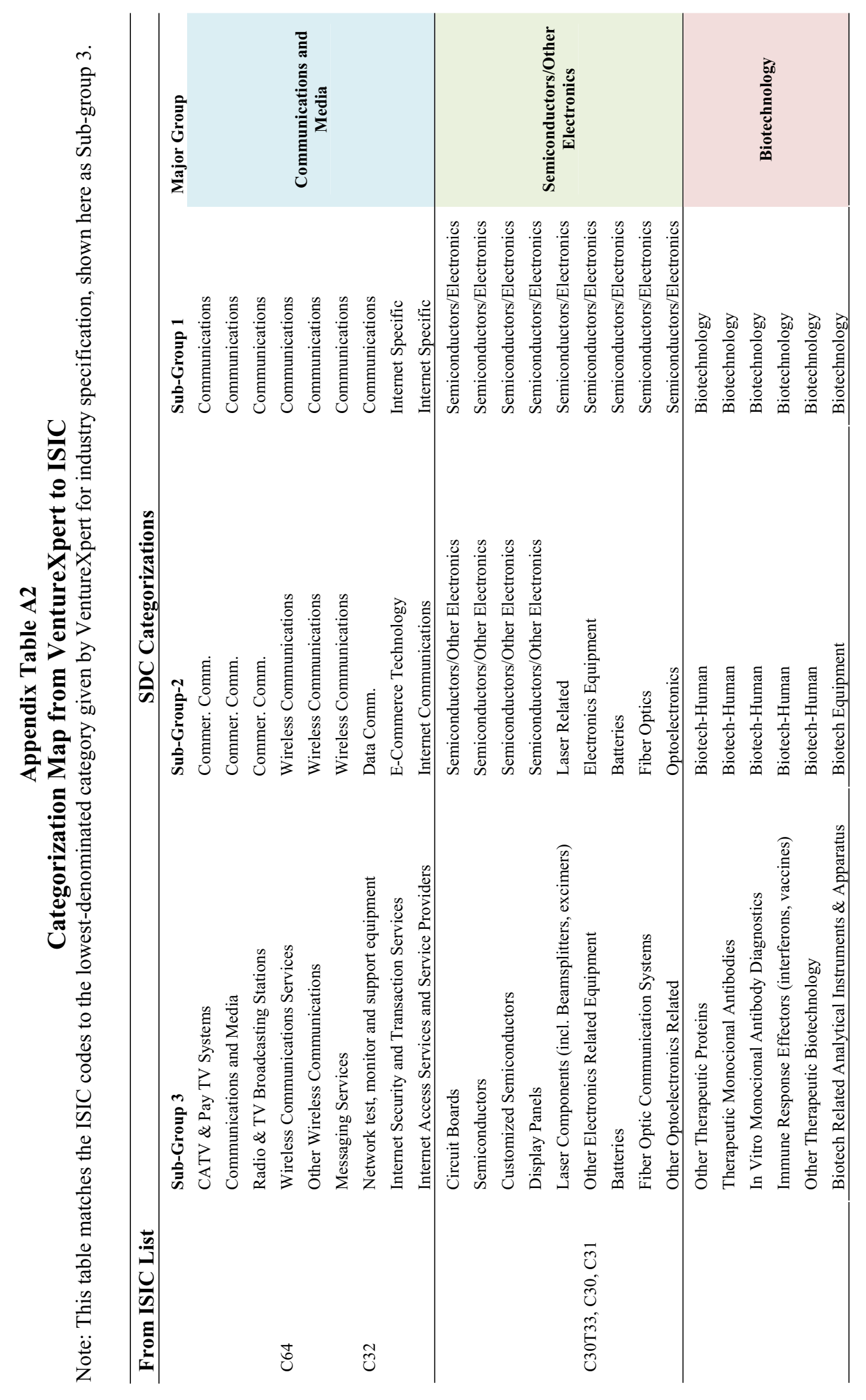




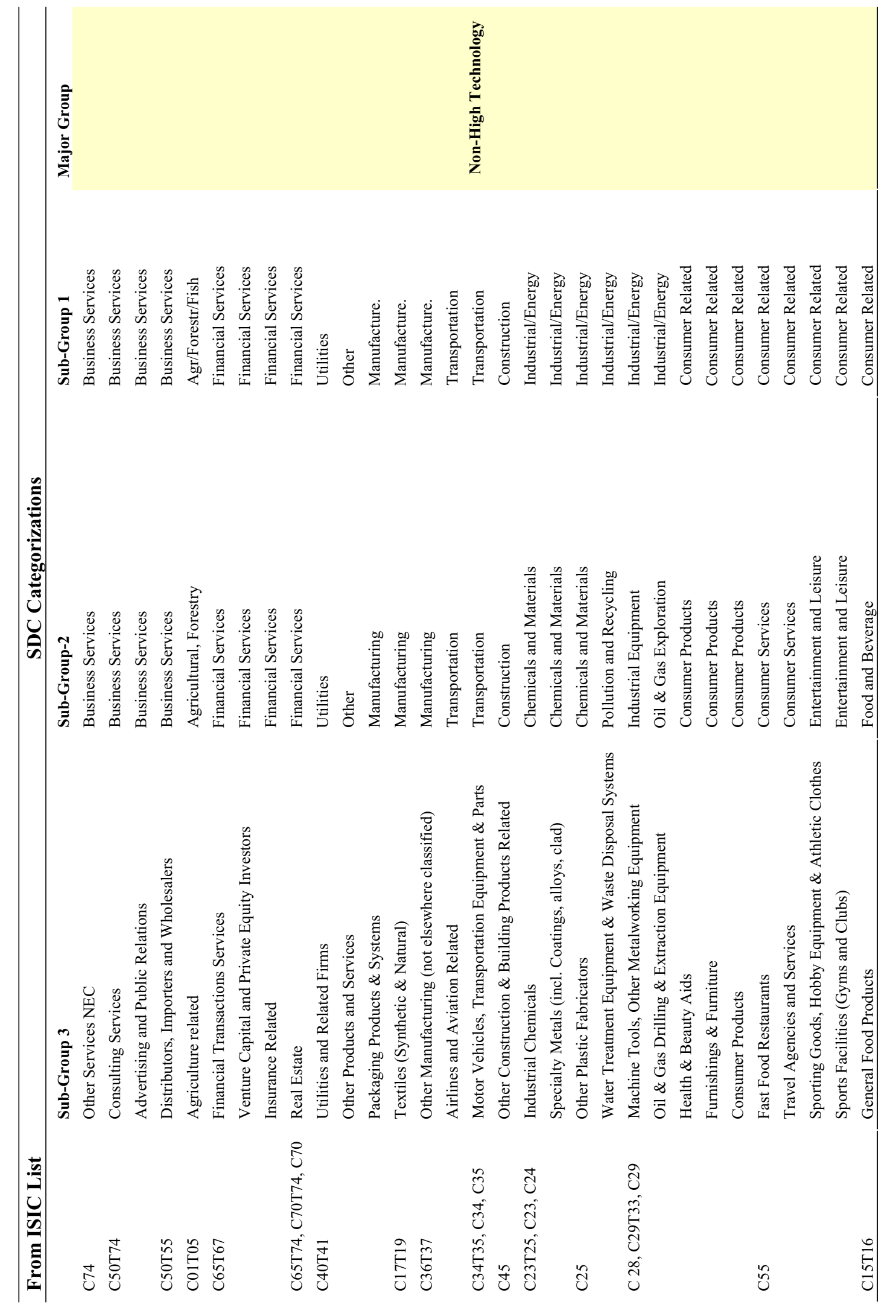




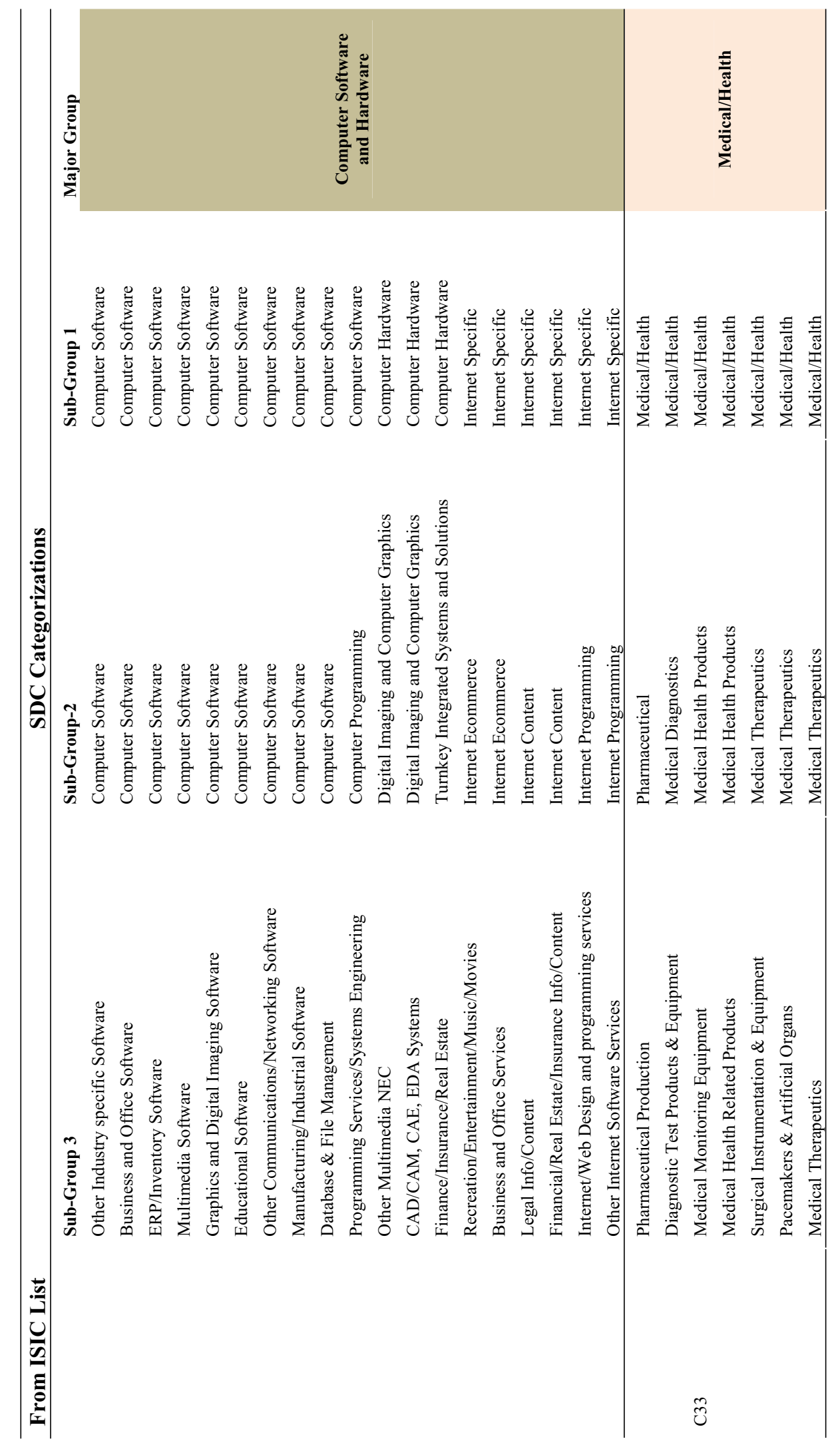




\section{Appendix Table A3 \\ Success by Exit via IPO and M\&A, controlling by GDP growth}

Notes: Success by IPO and Success by $M \& A$ are computed as the number of firms who successfully exited via IPO (merging with or being acquired by other firms, respectively) divided by the total number of firms receiving venture capital funding, between 1985 and 2008, by industry and country, multiplied by a factor of 100. Average investment per firm is measured in millions of Euro. Real GDP growth takes the average growth rate over the period 1985-2007 multiplied by a factor of 100 , while $R \& D$ per capita is measured in thousands of Euro. The number of patents is per 1,000 inhabitants. Robust standard errors are in parentheses. $* * *, * *$, and $*$ determine significance at the $1 \%, 5 \%$, and $10 \%$ levels, respectively.

\begin{tabular}{|c|c|c|c|c|}
\hline & $\begin{array}{l}\text { Success by IPO } \\
\text { (all countries) }\end{array}$ & $\begin{array}{l}\text { Success by IPO } \\
\text { (excl. U.S.) }\end{array}$ & $\begin{array}{c}\text { Success by } \\
\text { M\&A } \\
\text { (all countries) }\end{array}$ & $\begin{array}{c}\text { Success by } \\
\text { M\&A } \\
\text { (excl. U.S.) }\end{array}$ \\
\hline Average investment per firm & $\begin{array}{l}0.308 * * * \\
(0.070)\end{array}$ & $\begin{array}{c}0.276 * * * \\
(0.097)\end{array}$ & $\begin{array}{l}0.370 * * * \\
(0.072)\end{array}$ & $\begin{array}{c}0.250 * * * \\
(0.078)\end{array}$ \\
\hline Real GDP growth & $\begin{array}{l}-0.765 \\
(0.521)\end{array}$ & $\begin{array}{l}-0.900^{*} \\
(0.532)\end{array}$ & $\begin{array}{l}1.968 * * * \\
(0.562)\end{array}$ & $\begin{array}{l}1.681 * * * \\
(0.561)\end{array}$ \\
\hline R\&D per capita & $\begin{array}{l}9.140^{*} \\
(4.568)\end{array}$ & $\begin{array}{l}9.590 * * \\
(4.513)\end{array}$ & $\begin{array}{c}2.306 \\
(3.701)\end{array}$ & $\begin{array}{l}4.256 \\
(3.794)\end{array}$ \\
\hline Patents & $\begin{array}{l}-0.603 \\
(0.454)\end{array}$ & $\begin{array}{c}-0.780 * \\
(0.462)\end{array}$ & $\begin{array}{c}0.406 \\
(0.372)\end{array}$ & $\begin{array}{l}-0.007 \\
(0.383)\end{array}$ \\
\hline Computer Hardware and Software & $\begin{array}{c}0.164 \\
(0.806)\end{array}$ & $\begin{array}{c}0.389 \\
(0.831)\end{array}$ & $\begin{array}{c}3.145^{* * *} \\
(1.120)\end{array}$ & $\begin{array}{c}2.235 * * \\
(0.888)\end{array}$ \\
\hline Semi-Conductors / Other Electronics & $\begin{array}{l}-0.671 \\
(1.122)\end{array}$ & $\begin{array}{l}-0.569 \\
(1.201)\end{array}$ & $\begin{array}{c}1.915 \\
(1.616)\end{array}$ & $\begin{array}{c}1.612 \\
(1.712)\end{array}$ \\
\hline Biotechnology & $\begin{array}{l}3.076^{*} \\
(1.709)\end{array}$ & $\begin{array}{c}2.707 \\
(1.728)\end{array}$ & $\begin{array}{c}-2.443 * * * \\
(0.956)\end{array}$ & $\begin{array}{c}-2.420 * * \\
(1.014)\end{array}$ \\
\hline Medical / Health / Life Sciences & $\begin{array}{l}2.267^{*} \\
(1.294)\end{array}$ & $\begin{array}{c}2.133 \\
(1.332)\end{array}$ & $\begin{array}{l}-1.484 \\
(1.241)\end{array}$ & $\begin{array}{l}-1.716 \\
(1.309)\end{array}$ \\
\hline Communications and Media & $\begin{array}{c}0.703 \\
(1.495)\end{array}$ & $\begin{array}{c}1.189 \\
(1.551)\end{array}$ & $\begin{array}{l}5.351 * * * \\
(1.801)\end{array}$ & $\begin{array}{l}5.401 * * * \\
(1.822)\end{array}$ \\
\hline Adjusted R-squared & 0.421 & 0.338 & 0.553 & 0.419 \\
\hline No. of Observations & 84 & 78 & 84 & 78 \\
\hline
\end{tabular}




\section{Appendix Table A4}

\section{Success by Stage of Funding, controlling by GDP growth}

Notes: Success by Infant Firms and Success by Mature Firm are computed as the number of start-up and seed, and early-stage firms (mature firms, respectively), who successfully exited by going public, merger and acquisition, or leveraged buy-outs, divided by the total number of start-up and seed, and early-stage firms (mature firms, respectively) which received venture capital funding, between 1985 and 2008, by industry and country, multiplied by a factor of 100. Average investment per firm is measured in millions of Euro. Real GDP growth takes the average growth rate over the period 1985-2007 multiplied by a factor of 100 , while $R \& D$ per capita is measured in thousands of Euro. The number of patents is per 1,000 inhabitants. Robust standard errors are in parentheses. $* * *, * *$, and $*$ determine significance at the $1 \%, 5 \%$, and $10 \%$ level, respectively.

\begin{tabular}{|c|c|c|c|c|}
\hline & $\begin{array}{l}\text { Success of } \\
\text { Infant firms } \\
\text { (all countries) }\end{array}$ & $\begin{array}{l}\text { Success of } \\
\text { Infant firms } \\
\text { (excl. U.S.) }\end{array}$ & $\begin{array}{c}\text { Success of } \\
\text { Mature firms } \\
\text { (all countries) }\end{array}$ & $\begin{array}{l}\text { Success of } \\
\text { Mature firms } \\
\text { (excl. U.S.) }\end{array}$ \\
\hline Average investment per firm & $\begin{array}{c}0.710 * * * \\
(0.139)\end{array}$ & $\begin{array}{c}0.476 * * * \\
(0.171)\end{array}$ & $\begin{array}{c}0.680 * * * \\
(0.165)\end{array}$ & $\begin{array}{c}0.762 * * * \\
(0.276)\end{array}$ \\
\hline Real GDP growth & $\begin{array}{l}1.171 \\
(1.029)\end{array}$ & $\begin{array}{c}0.586 \\
(1.508)\end{array}$ & $\begin{array}{c}-3.242 * * \\
(1.476)\end{array}$ & $\begin{array}{c}-3.230 * * \\
(1.618)\end{array}$ \\
\hline R\&D per capita & $\begin{array}{l}9.178 \\
(7.614)\end{array}$ & $\begin{array}{c}12.959 * \\
(7.700)\end{array}$ & $\begin{array}{c}9.263 \\
(8.397)\end{array}$ & $\begin{array}{c}7.709 \\
(8.012)\end{array}$ \\
\hline Patents & $\begin{array}{l}-0.484 \\
(0.657)\end{array}$ & $\begin{array}{c}-1.320^{*} \\
(0.753)\end{array}$ & $\begin{array}{l}-0.945 \\
(0.859)\end{array}$ & $\begin{array}{l}-0.872 \\
(0.945)\end{array}$ \\
\hline Computer Hardware and Software & $\begin{array}{c}6.388 * * * \\
(1.923)\end{array}$ & $\begin{array}{c}5.616 * * * \\
(1.963)\end{array}$ & $\begin{array}{c}-12.041 * * * \\
(2.371)\end{array}$ & $\begin{array}{c}-12.969 * * * \\
(2.443)\end{array}$ \\
\hline Semi-Conductors / Other Electronics & $\begin{array}{l}4.855 \\
(3.296)\end{array}$ & $\begin{array}{l}4.878 \\
(3.477)\end{array}$ & $\begin{array}{c}-6.596^{*} \\
(3.486)\end{array}$ & $\begin{array}{c}-7.403 * * \\
(3.664)\end{array}$ \\
\hline Biotechnology & $\begin{array}{c}6.994 * * * \\
(2.488)\end{array}$ & $\begin{array}{c}7.225 * * * \\
(2.762)\end{array}$ & $\begin{array}{c}-14.796^{* * * *} \\
(4.961)\end{array}$ & $\begin{array}{c}-16.653 * * * \\
(5.407)\end{array}$ \\
\hline Medical / Health / Life Sciences & $\begin{array}{l}5.861 * \\
(3.243)\end{array}$ & $\begin{array}{l}5.933^{*} \\
(3.302)\end{array}$ & $\begin{array}{l}-4.734 \\
(3.573)\end{array}$ & $\begin{array}{l}-5.765 \\
(3.857)\end{array}$ \\
\hline Communications and Media & $\begin{array}{c}10.902 * * * \\
(2.280)\end{array}$ & $\begin{array}{c}11.815^{* * * *} \\
(2.397)\end{array}$ & $\begin{array}{l}-5.299 \\
(3.399)\end{array}$ & $\begin{array}{l}-5.316 \\
(3.578)\end{array}$ \\
\hline Adjusted R-squared & 0.414 & 0.287 & 0.368 & 0.360 \\
\hline No. of Observations & 84 & 78 & 84 & 78 \\
\hline
\end{tabular}




\section{CFS Working Paper Series:}

\begin{tabular}{|c|c|c|}
\hline No. & Author(s) & Title \\
\hline $2010 / 01$ & $\begin{array}{l}\text { Nikolaus Hautsch } \\
\text { Dieter Hess } \\
\text { David Veredas }\end{array}$ & $\begin{array}{l}\text { The Impact of Macroeconomic News on Quote } \\
\text { Adjustments, Noise, and Informational } \\
\text { Volatility }\end{array}$ \\
\hline $2009 / 32$ & $\begin{array}{l}\text { Guenter W. Beck } \\
\text { Kirstin Hubrich } \\
\text { Massimiliano Marcellino }\end{array}$ & $\begin{array}{l}\text { On the importance of sectoral shocks for } \\
\text { price-setting }\end{array}$ \\
\hline $2009 / 31$ & $\begin{array}{l}\text { Axel Groß-Klußmann } \\
\text { Nikolaus Hautsch }\end{array}$ & $\begin{array}{l}\text { Quantifying High-Frequency Market Reactions } \\
\text { to Real-Time News Sentiment } \\
\text { Announcements }\end{array}$ \\
\hline $2009 / 30$ & Volker Wieland & $\begin{array}{l}\text { Quantitative Easing: } \\
\text { A Rationale and Some Evidence from Japan }\end{array}$ \\
\hline $2009 / 29$ & $\begin{array}{l}\text { Dimitris Georgarakos } \\
\text { Giacomo Pasini }\end{array}$ & $\begin{array}{l}\text { Trust, Sociability and Stock Market } \\
\text { Participation }\end{array}$ \\
\hline $2009 / 28$ & $\begin{array}{l}\text { Dimitris Christelis } \\
\text { Dimitris Georgarakos }\end{array}$ & $\begin{array}{l}\text { Investing at Home and Abroad: Different } \\
\text { Costs, Different People? }\end{array}$ \\
\hline
\end{tabular}

2009/27 Erik Theissen

Price Discovery in Spot and Futures Markets: A Reconsideration

2009/26 Volker Wieland

Fiscal Stimulus and the Promise of Future Spending Cuts: A Comment

\section{9/25 Tobias Cwik Volker Wieland}

2009/24 Otmar Issing
Keynesian government spending multipliers and spillovers in the euro area

Politischer Wille oder ökonomisches Gesetz?

- Einige Anmerkungen zu einem großen Thema -

Copies of working papers can be downloaded at http://www.ifk-cfs.de 